\title{
Effects of Fly Ash and Granulated Ground Blast Furnace Slag on Stabilization of Crude Oil Contamination Sandy Soil
}

\author{
Farman Ghaffoori', Mohamed Arbili ${ }^{2 *}$ \\ ${ }^{1}$ Hasan Kalyoncu University, Gaziantep, Turkey, ${ }^{2}$ Department of Information Technology, Choman Technical Institute, Erbil Polytechnic \\ University, Erbil, Kurdistan Region, Iraq
}

\section{*Corresponding author: Mohamed Arbili, \\ Department of Information Technology, Choman Technical Institue, Erbil Polytechnic University, Kurdistan Region, Iraq. Phone: 07504165003. \\ E-mail: mohamed.arbili@epu. edu.iq}

\begin{tabular}{l} 
Received: 20 August 2019 \\
Accepted: 05 September 2019 \\
Published: 01 December \\
2019 \\
\hline DOI \\
10.25156/ptj.v9n2y2019.pp80-85
\end{tabular}

\section{A B S TR A C T}

This paper deals with on stabilization of crude oil-contaminated soil. Industrial waste materials such as GGBFS and fly ash (FA) are used to achieve acceptable results for compaction and strength properties. GGBFS and FA utilized in two groups of soil (clean soil and $6 \%$ contaminated with crude oil) with varying proportions of GGBFS and FA by weight of soil. The primary goals of this study explain to establish a conclusion that GGBFS and FA are the best byproduct stabilizer material for increasing the strength and stability of soil by investigating samples of soil. In this study, the effect of GGBFS and FA on compaction properties (OMC and MDD) and direct shear strength (cohesion and angle of friction) observed. Different percentages of GGBFS $(0 \%, 10 \%$, and $15 \%)$ and FA $(0 \%, 10 \%$, and $15 \%)$ by dry weight were utilized in mixtures of sandy soil samples for different experiments. Ultimately, bases on the experimental results, it is summarized that the use of industrial wastes, i.e. GGBFS and Flyash, are affected in shear strength and compaction properties. Although, they have environment-friendly behavior for the construction project purpose.

Keywords: ANOVA; Compaction; Fly ash; GGBFS Slag; Strength

\section{INTRODUCTION}

Stabilization is necessary for highway and runway construction, stabilization indicates an improvement in both shear strength and stability which are related to the performance of soil. The emphasis is placed on the effective utilization of wastes by-products such as Fly ash (FA) and Steel Slag and FA, to decrease the construction cost and enhance the soil durability. This new procedure of soil stabilization can be effectively utilized to meet the present challenges of society, to decrease the quantities of waste, producing serviceable material from no useful waste material. Globally, FA and Steel Slag are considered as best byproducts that can be used for many utilizations.

Several researchers studied the negative characteristics of sandy soil by adding it with additives such as lime, clay, cement, FA, and Steel Slag. There has been recent interest globally in the use of steel slag in various civil engineering applications, due to economic advantages and environmental protection.

Ashish Kumar Pathak et al. (2014) mentioned the soil stabilization utilizing steel slag which was taken in the blast furnace of a cement plant, which is then produced from iron (ACC Plant, Sindri). They showed the influence of different proportions of GGBFS $(0-25 \%)$ on various engineering properties (MDD, OMC, PL, LL, CBR value, UCS, and triaxial test) was investigated in soil, in the results described a significant development in soil strength properties after addition of steel slag.

Osman Sivrikaya et al. (2014) studied the influence of steel slag on the index properties and compaction properties of soils. The steel slag was procured from the Iskenderun Iron and Steel Plant as manufacturing waste. The influence of steel slag was investigated in various proportions $(5,10,20,30$, and $50 \%)$. Result of the tests illustrated that steel slag has a positive effect on the stabilization of soils. Sabbar et al. (2017) studied the Shear Strength Parameters of Sand-Slag Mixtures. Using steel slag has a positive impact on the ecological, as it decreases carbon dioxide emissions and other issues associated with waste destruction. Furthermore, utilizing slag in engineering construction projects may decrease the cost of building and preserve resources.

According to a study by (Ahmaruzzaman, 2010), FA as a raw material can be appropriated in the construction of geotechnical engineering and geoenvironmental infrastructures. To reduce the amount of waste materials, reuse materials like FA in highway and engineering projects (Cetin and Aydilek, 2013). Bumjoo et al. (2005) conducted the appropriateness of bottom and FA mixture in highway 
embankment engineering construction projects. He was found that the best dry density lowered while the optimum water content increased with an increased FA content from $50 \%$ to $100 \%$ (Bumjoo et al., 2005).

Dayalan (2016) investigated the improvement of soil with FA and steel slag. Stabilization of soil has become the main problem in construction engineering projects and rapidly improving utilizing industrial waste materials as a stabilizer to minimize the amount of waste to be disposed to the environment causing environmental deterioration. Different percentages of $5,10,15$, and $20 \%$ by dry weight of steel slag and FA are added separately with soil to recognize the stabilization of soil.

Oormila et al. (2014) used steel slag and FA to support soils economically and environmentally friendly way. Different amounts of steel slag $(15 \%, 20 \%$, and $25 \%)$ and FA (5\%, $10 \%, 15 \%$, and $20 \%$ ) were mixed with the soil by dry weight and performed strength tests. In the present research, the effect of steel slag and FA appraised on stabilization of crude oil contamination sandy soil by compaction and shear strength test.

\section{MATERIALS AND SAMPLE PREPARATION}

\section{Materials \\ Sand}

The soil sample was used in the laboratory test sandy soil. The grain-size distribution of the sand is determined from hydrometer tests according to ASTM Standard Test Method D 422-63, as shown in Figure 1.

\section{Crude oil}

The crude oil used has its specific gravity at $25.0^{\circ} \mathrm{C}$ to be 0.851 and its American Petroleum Institute (API) gravity at $25.0^{\circ} \mathrm{C}$ to be $23.261^{\circ}$ API [Table 1 ].

\section{Ground granulated blast furnace slag (GGBFS)}

GGBFS was manufactured by pulverizing granulated blast furnace. Slag is mixed with FA to stabilize contaminated soil by crude oil. The chemical combination of a slag differs considerably, relying on the composition of the raw materials in the iron production process. The main elements of blast furnace slag are $\mathrm{Al}_{2} \mathrm{O}_{3}, \mathrm{SiO}_{2}, \mathrm{MgO}$, and $\mathrm{CaO}$. In comprehensive, $\mathrm{CaO}$ content of the rising slag results in increased slag basicity and an increase in compressive strength. The chemical properties of slag are shown in Table 2.

\section{FA}

FA is usually captured by electrostatic precipitators or other particle filtration machines before the flue gases reach the chimneys. FA collected from the bottom of the boiler; it recognized as coal ash. Based on the source and composition of the coal burned, the components of FA vary significantly. However, all FA includes valuable amounts of calcium oxide $(\mathrm{CaO})$, aluminum oxide $\left(\mathrm{Al}_{2} \mathrm{O}_{3}\right)$, and silicon dioxide $\left(\mathrm{SiO}_{2}\right)$, the leading mineral composites in coal-bearing rock strata. Other mineral admixture mixed with FA in different percentage. The enhanced mixture necessity possesses stability and adequate strength, should

Table 1: Properties of crude oil

\begin{tabular}{lcccc}
\hline Sample & $\begin{array}{c}\text { Flash } \\
\text { Point }{ }^{\circ} \mathrm{C}\end{array}$ & $\begin{array}{c}\text { Density at } \\
25^{\circ} \mathbf{C}\left(\mathrm{g} / \mathrm{cm}^{3}\right)\end{array}$ & API & $\begin{array}{c}\text { Viscosity } \\
(\mathrm{Cp})\end{array}$ \\
\hline Kar Refinery & 53 & 0.849 & 23.261 & 18.2 \\
\hline
\end{tabular}

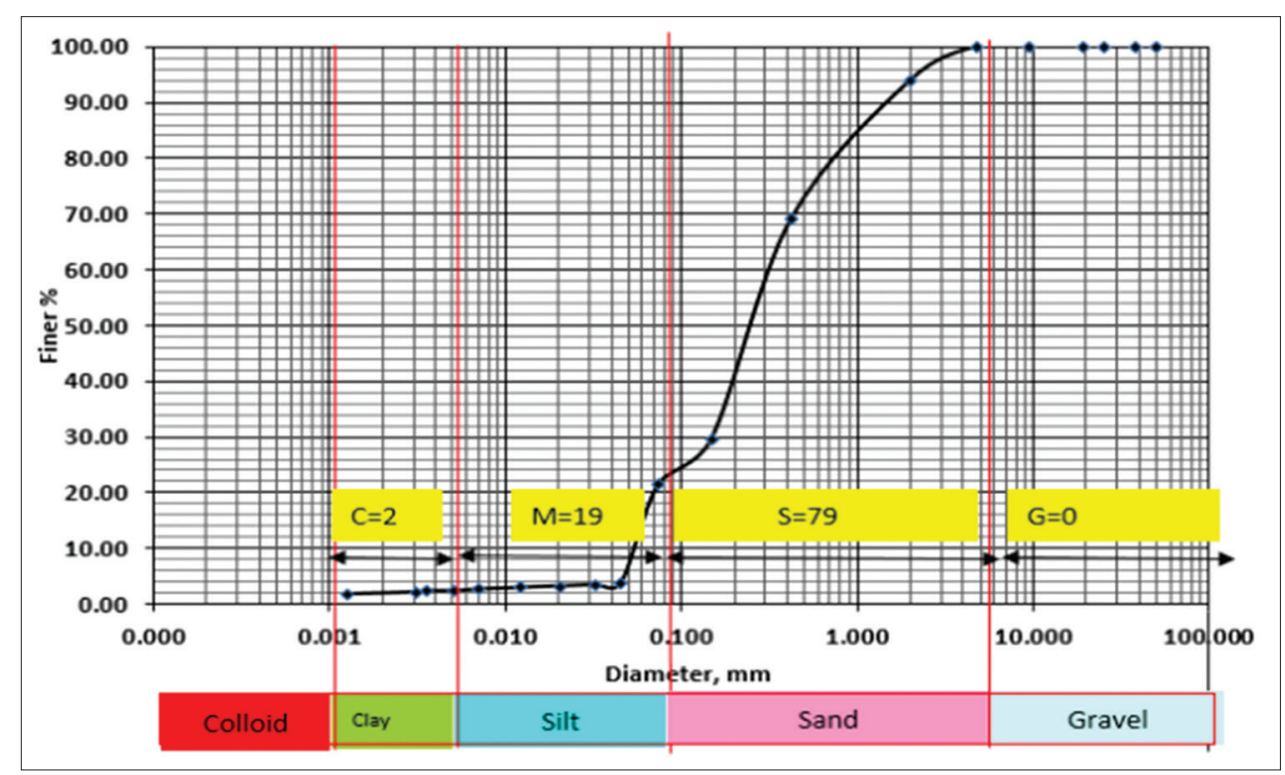

Figure 1: Particle size distribution curve for soil samples 
be economical, easily compacted, and environmentally friendly. The chemical properties of FA are shown in Table 2.

\section{Sample Preparation}

The soil used in this study was obtained from Lajan area, having a sandy soil profile, at Erbil Governorate, Kurdistan region, Iraq. It was collected from the site of the soil profile at about $50 \mathrm{~cm}$ depth below the ground surface to prevent upper organic soil layers from entering the sample soils. Before the commencement of laboratory tests on the soil samples collected in sacks and transported to the laboratory, they were passed through a $4.75 \mathrm{~mm}$ sieve and oven-dried, while the mix specimens were added $6 \%$ of crude oil by weight of the dry soil samples. The mixed samples were put into closed containers for 2 weeks foraging and equilibrium, allowing possible reactions between soil and crude oil. The contamination of the soil with varying percentages of crude oil did in the laboratory. GGBFS and FA were used in proportions of $0 \%, 10 \%$, and $15 \%$, and $0 \%, 10 \%$, and $15 \%$, respectively, by weight of soil sample for various experiments. Table 3 demonstrated the ratio of addition waste materials in two groups for nine mixes.

\section{RESULTS}

\section{Compaction}

Compaction test results demonstrated as optimum moisture content and maximum dry density. To show the effect of crude oil contamination and mineral admixtures such as ground granulated blast furnace slag and FA on

Table 2: Chemical composition of fly ash and GGBFS

\begin{tabular}{lcc}
\hline Elements & FA & GGBFS \\
\hline $\mathrm{SiO}_{2}$ & 38.81 & 60.69 \\
$\mathrm{Al}_{2} \mathrm{O}_{3}$ & 6.07 & 3.01 \\
$\mathrm{CaO}$ & 30.17 & 5.8 \\
$\mathrm{Fe}_{2} \mathrm{O}_{3}$ & 1.98 & 23.94 \\
$\mathrm{MgO}$ & 2.66 & 0.76 \\
$\mathrm{SO}_{3}$ & 2.21 & 1.56 \\
\hline
\end{tabular}

both compaction parameters with sandy soil. Soil samples prepared in two group uncontaminated and contaminated soil samples with crude oil, each group consist of nine mixtures with various percentage $(0 \%, 10 \%$, and $15 \%)$ from each of GGBFS and FA. In Figure 2 illustrated the effect of optimum moisture content in both group and each mixture, OMC decreased with added crude oil by $6 \%$ to the soil sample; it is due to the capillary effect. Usually, the spaces between soil particles could be considered as a capillary tube, which causes the rise of the water in it. While the compaction weight is falling on the soil, these spaces became thinner and thinner, which increases the capillary tension. When increased FA in group one, OMC increased in mix. 1,2, and 3. However, in other binary mixes significant effect on OMC; the highest value recorded in mix 8 which is contain (15\% of GGFBFS and $10 \%$ of FA).

The influence of crude oil contamination and mineral admixtures on the maximum dry density of sandy soil samples is shown in Figure 3. While increased FA maximum dry density decreased in both groups. GGBFS increased MDD and in binder mixes demonstrated that the effect of both mineral admixtures the peak value of MDD is in mix 7 with contaminated by oil in Group 2. Results for OMC and MDD are supported by the results of many researchers such as Mahvash et al. 2017 and Okonta and Govender, 2011, Sabbar et al. 2017.

\section{Direct Shear Test}

Shear strength parameters are cohesion and angle of internal friction (c and ф). Results obtained from this study are shown in Table 4. Cohesion increased with increase $\mathrm{FA}$ in mixes 1,2, and 3 in contaminated and uncontaminated soil samples. Furthermore, in binary mixes binder significant impact on the result of cohesion, peak value at mix 9 and contaminated soil sample with crude oil. Increased GGBFS also slightly increased the cohesion of soil. Although, huge difference value for cohesion between Group 1 and Groups 2 due to the effect of crude oil on sandy soil particles. This change of behavior is attributed

Table 3: Mix description for additional waste materials

\begin{tabular}{|c|c|c|c|c|c|c|c|c|c|}
\hline \multicolumn{10}{|c|}{ Group I } \\
\hline Mix. No. & Mix 1 & Mix 2 & Mix 3 & Mix 4 & Mix 5 & Mix 6 & $\operatorname{Mix} 7$ & Mix 8 & Mix 9 \\
\hline Crude oil\% & 0 & 0 & 0 & 0 & 0 & 0 & 0 & 0 & 0 \\
\hline Slag (GGBFS) & 0 & 0 & 0 & 10 & 10 & 10 & 15 & 15 & 15 \\
\hline Fly ash (FA) & 0 & 10 & 15 & 0 & 10 & 15 & 0 & 10 & 15 \\
\hline Soil & 100 & 90 & 85 & 90 & 80 & 75 & 85 & 75 & 70 \\
\hline \multicolumn{10}{|c|}{ Group II } \\
\hline Mix. No. & Mix 1 & Mix 2 & Mix 3 & Mix 4 & Mix 5 & Mix 6 & $\operatorname{Mix} 7$ & Mix 8 & Mix 9 \\
\hline Crude oil\% & 6 & 6 & 6 & 6 & 6 & 6 & 6 & 6 & 6 \\
\hline Slag (GGBFS) & 0 & 0 & 0 & 10 & 10 & 10 & 15 & 15 & 15 \\
\hline Fly ash (FA) & 0 & 10 & 15 & 0 & 10 & 15 & 0 & 10 & 15 \\
\hline Soil & 94 & 84 & 79 & 84 & 74 & 69 & 79 & 69 & 64 \\
\hline
\end{tabular}




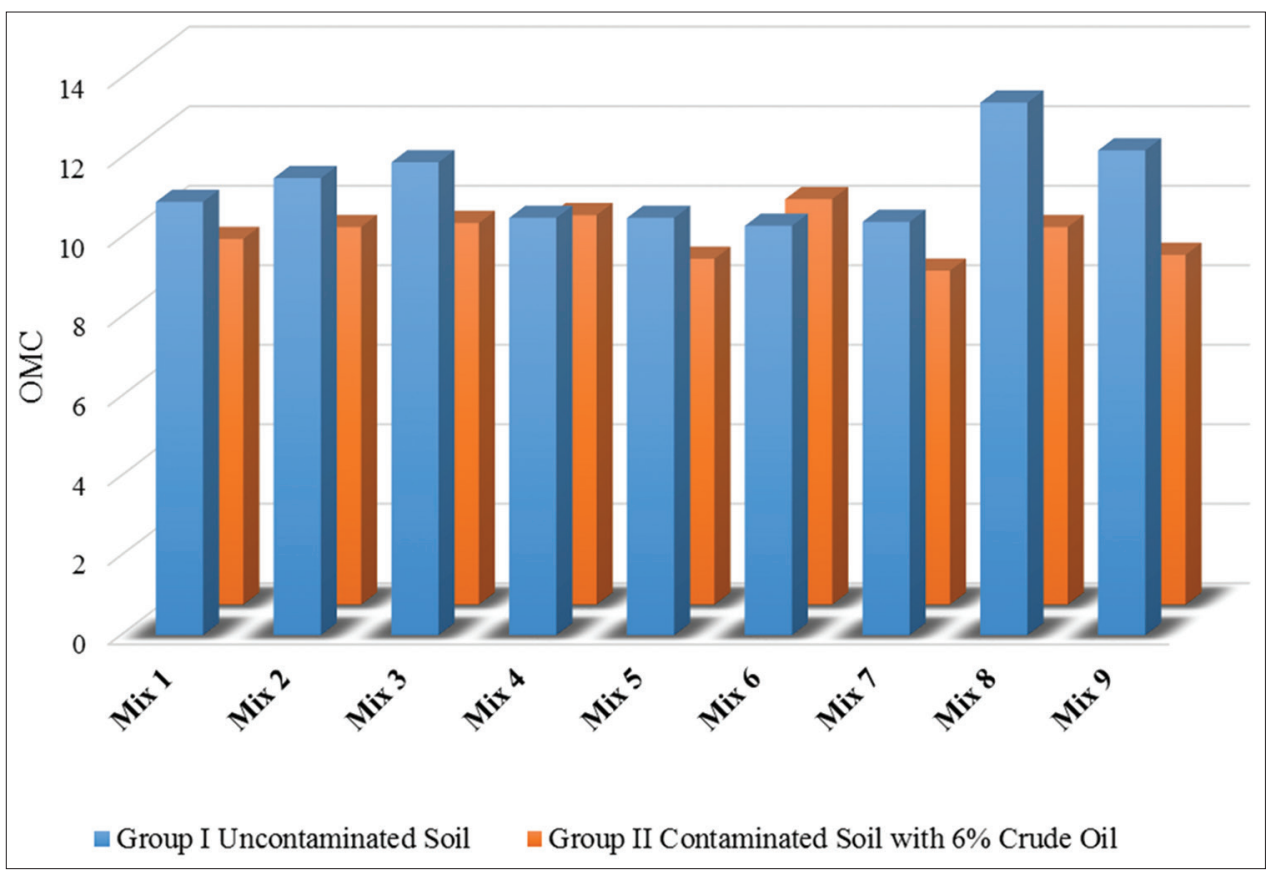

Figure 2: Variation of OMC values with different waste materials content in sandy soil

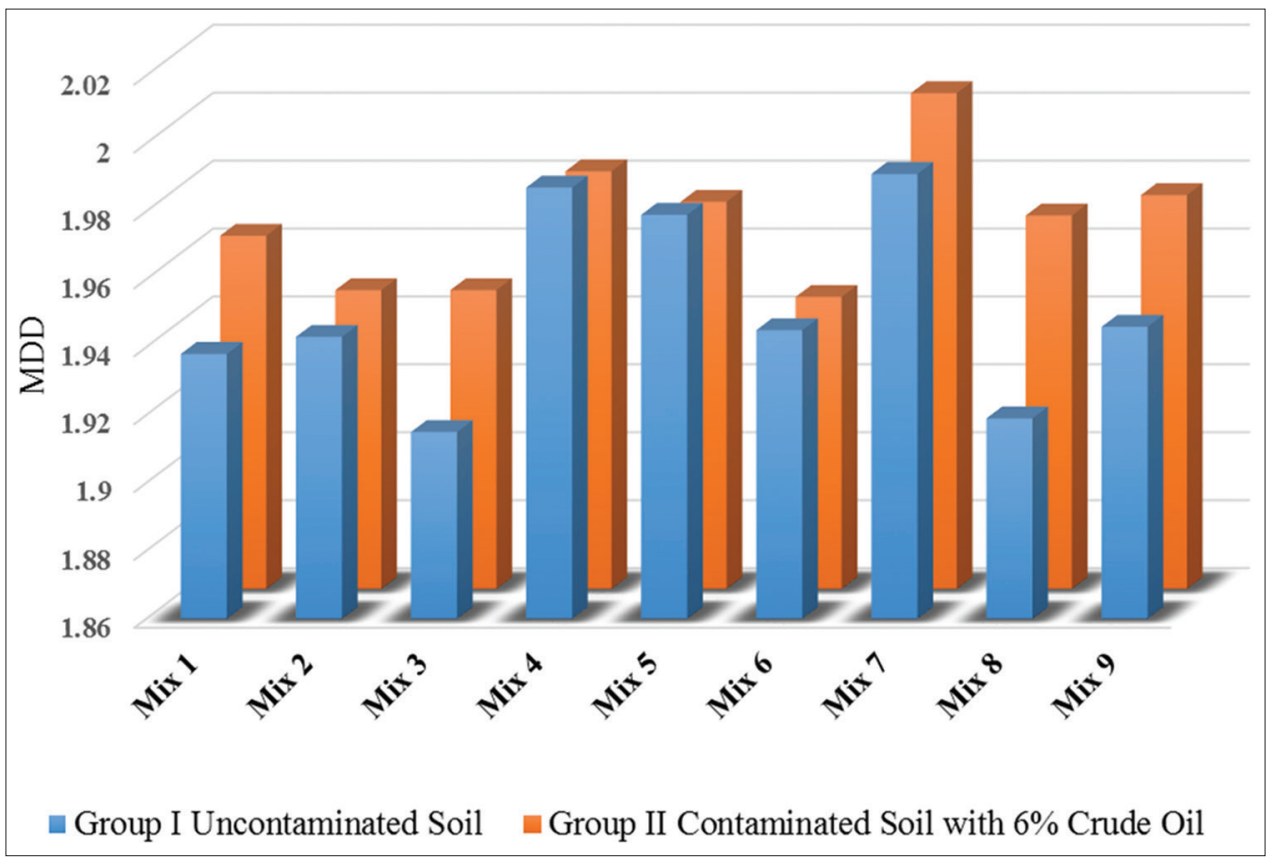

Figure 3: Variation of MDD values with different waste materials content in sandy soil

to the viscous properties of the contaminants which helps in bringing the individual soil particles more close together hence making it into a more compact configuration. Results are agreement with Sabbar et al., 2017 and Consoli et al., 2001. The angle of internal friction is decreased with added crude oil for soil sample, regarding to fa decreased (d) with increased it. Results close to gather with the change in percentage of GGBFS in binder in both groups. In Table 4, the result of the direct shear in two groups.

\section{Statistical Analysis}

All the data have been entered and processed using Minitab (Version 18). Analysis of variance (ANOVA) at $95 \%$ confidence level has been applied to find the statistical significance of the factors. In this study, the main parameters are crude oil, slag, and FA considered as the design factors, and the design responses defined as OMC, MDD, Cohesion, and $\phi$. In addition, ANOVA is performed to recognize the level of effectiveness 
Table 4: Result of the direct shear test

\begin{tabular}{|c|c|c|c|c|c|c|c|c|c|}
\hline \multicolumn{10}{|c|}{ Group I } \\
\hline Mix. No. & Mix 1 & Mix 2 & Mix 3 & Mix 4 & Mix 5 & Mix 6 & Mix 7 & Mix 8 & Mix 9 \\
\hline (c ) & 0.786 & 4.97 & 12 & 9.71 & 20 & 19.6 & 25.7 & 21.9 & 15.9 \\
\hline ( $\varphi$ ) Phi & 42.8 & 34.7 & 34.7 & 37.5 & 39.3 & 39.9 & 37.5 & 32.1 & 42.5 \\
\hline \multicolumn{10}{|c|}{ Group II } \\
\hline Mix. No. & Mix 1 & Mix 2 & Mix 3 & Mix 4 & Mix 5 & Mix 6 & Mix 7 & Mix 8 & Mix 9 \\
\hline (c ) & 31.9 & 46.7 & 50.8 & 51.2 & 69.3 & 68.5 & 67 & 68.3 & 72.7 \\
\hline ( $\varphi)$ Phi & 38.7 & 36.5 & 33.7 & 31.6 & 27.7 & 29.7 & 33.2 & 34.1 & 34.1 \\
\hline
\end{tabular}

Table 5: ANOVA results for the considered dependent variables

\begin{tabular}{|c|c|c|c|c|c|c|}
\hline \multirow[t]{2}{*}{ Dependent variables } & \multirow[t]{2}{*}{ Source of variation } & \multicolumn{5}{|c|}{ Statistical parameters } \\
\hline & & DF & Adj SS & Adj MS & F-Value & P-value \\
\hline \multirow[t]{5}{*}{$\mathrm{OMC}$} & Crude oil\% & 1 & 17.8006 & 17.8006 & 23.47 & 0 \\
\hline & Slag (GGBFS) & 2 & 0.7811 & 0.3906 & 0.52 & 0.61 \\
\hline & Fly ash (FA) & 2 & 1.6478 & 0.8239 & 1.09 & 0.368 \\
\hline & Error & 12 & 9.1 & 0.7583 & & \\
\hline & Total & 17 & 29.3294 & & & \\
\hline \multirow[t]{5}{*}{ MDD } & Crude oil\% & 1 & 0.001284 & 0.001284 & 4.51 & 0.055 \\
\hline & Slag (GGBFS) & 2 & 0.002672 & 0.001336 & 4.7 & 0.031 \\
\hline & Fly ash (FA) & 2 & 0.003277 & 0.001639 & 5.76 & 0.018 \\
\hline & Error & 12 & 0.003414 & 0.000285 & & \\
\hline & Total & 17 & 0.010648 & & & \\
\hline \multirow[t]{5}{*}{ C } & Crude oil\% & 1 & 8704.7 & 8704.7 & 238.65 & 0 \\
\hline & Slag (GGBFS) & 2 & 1381.8 & 690.89 & 18.94 & 0 \\
\hline & Fly ash (FA) & 2 & 273 & 136.49 & 3.74 & 0.055 \\
\hline & Error & 12 & 437.7 & 36.47 & & \\
\hline & Total & 17 & 10797.2 & & & \\
\hline \multirow[t]{5}{*}{$\phi$} & Crude oil\% & 1 & 96.6 & 96.605 & 7.74 & 0.017 \\
\hline & Slag (GGBFS) & 2 & 19.76 & 9.882 & 0.79 & 0.475 \\
\hline & Fly ash (FA) & 2 & 24.14 & 12.071 & 0.97 & 0.408 \\
\hline & Error & 12 & 149.71 & 12.475 & & \\
\hline & Total & 17 & 290.22 & & & \\
\hline
\end{tabular}

of the independent variables on the design responses. $\mathrm{p}$-values for results of the statistical analysis demonstrated in Table 5, which is higher than 0.05, the parameter rejected as an insignificant factor on the response at 95\% confidence level, such as slag and FA in OMC, $\phi$. Furthermore, the much effective results achieved in Cohesion response, as shown in Table 5.

\section{CONCLUSION}

The outcome of the study has illustrated the influence of the mineral admixture (FA and GGBFS) on the clean and contaminated sandy soil with $6 \%$ crude oil. In addition, these minerals enhanced the compactions and shear strength parameter of the sandy soils.

On the other hand, in highway, and embankment constructions reduce the cost of projects and environmentfriendly due to the use of disposal industrial waste materials.

\section{REFERENCES}

Ahmaruzzaman, M. 2010. A review on the utilization of fly ash. Prog. Energy Combust. Sci. 36(3): 327-363.

Arbili, M. M. 2016. Soft computing based modelling of sorptivity of concretes incorporating mineral admixtures. ZANCO J. Pure Appl. Sci. 28(2): 574-579.

Arbili, M. M. 2016. Statistical analysis of the performance of the soft computing based prediction model for shrinkage of concrete including mineral admixtures. ZANCO J. Pure Appl. Sci. 28(2): 574-579.

Arbili, M. M. and M. Karpuzcu. 2018. Effect of crude oil contamination on physical and chemical properties of soil of Tarjan refineries Erbil province-North of Iraq. Polytech. J. 8(2): 159-170.

Cetin, B. and A. H. Aydilek. 2013. pH and fly ash type effect on trace metal leaching from embankment soils. Resour. Conserv. Recycl. 80: 107-117.

Consoli, N. C., P. D. M. Prietto, J. A. H. Carraro and K. S. Heineck. 2001. Behavior of compacted soil-fly ash-carbide lime mixtures. J. Geotech. Geo-Environ. Eng. 127(9): 774-782.

Dayalan, J. and J. Dayalan. 2016. Comparative study on stabilization of soil with ground granulated blast furnace slag (GGBS) and fly ash. Int. Res. J. Eng. Technol. 3(5): 5. 
Ghaffoori, F. K. and M. Karpuzcu. 2018. Influence of oil contamination on geotechnical properties of sandy soil. Polytech. J. 8(2): 129-141.

Karpuzcu, M., M. Arbili, F. Ghaffoori and A. Cabalar. 2018. An Assessment of the Effects of Light Crude Oil on the Geotechnical Properties of Asoil. Available from: http://www.ijamce.iraj.in/ paper_detail.php?paper_id=13875\&name $=$ an_assessment_ of_the_effects_of_light_crude_oil_on_the_geotechnical_ properties_of_asoil. [Last accessed on 2019 Aug 18].

Kim, B., M. Prezzi and R. Salgado. 2005. Geotechnical properties of fly and bottom ash mixtures for use in highway embankments. J. Geotech. Geo-Environ. Eng. 131(7): 914-924.

Mahvash, S., S. López-Querol and A. Bahadori-Jahromi. 2017. Effect of class $\mathrm{F}$ fly ash on fine sand compaction through soil stabilization. Heliyon. 3(3): e00274.

Okonta, F. N. and E. Govender. 2011. Effect of desiccation on the geotechnical properties of lime-fly ash stabilized collapsible residual sand. J. Eng. Appl. Sci. 6(6): 62-69.

Oormila, T. R. and T. V. Preethi. 2014. Effect of stabilization using flyash and GGBS in soil characteristics. Int. J. Eng. Trends Technol. 11(6): 284-289.

Pathak, A. K., V. Pandey, K. Murari and J. P. Singh. 2014. Soil stabilisation using ground granulated blast furnace slag. Int. J. Eng. Res. Appl. 4: 164-171.

Sabbar, A. S., A. Chegenizadeh and H. Nikraz. 2017. Effect of fines on liquefaction susceptibility of sandy soil. World academy of science, engineering and technology. Int. J. Environ. Chem. Ecol. Geol. Geophys. Eng. 11(11): 973-978.

Sivrikaya, O., K. R. Kıyıldı and Z. Karaca. 2014. Recycling waste from natural stone processing plants to stabilise clayey soil. Environ. Earth Sci. 71(10): 4397-4407. 